Halaman : 185- 192

\title{
ANALISIS SOAL UJIAN AKHIR SEMESTER MATA PELAJARAN BIOLOGI BERDASARKAN DIMENSI PROSES KOGNITIF TAKSONOMI ANDERSON
}

\author{
Indri Putri Utami ${ }^{1}$, Aryeni $^{2}$ \\ ${ }^{1,2}$ Program studi Pendidikan Biologi, Pendidikan Biologi, FMIPA, Universitas Negeri Medan, Medan, Jl. Wiliem \\ Iskandar Psr. V Medan Estate, Medan, Indonesia, 20221 \\ *E-mail: indripu7@gmail.com
}

\begin{abstract}
ABSTRAK
Penelitian ini bertujuan untuk menganalisis sebaran dimensi proses kognitif Taksonomi Anderson serta sebaran kompetensi dasar dan indikator pada soal ujian akhir semester ganjil biologi. Penelitian ini dilakukan di SMA Negeri 1 Kisaran Tahun Pembelajaran 2017/2018. Jenis penelitian ini adalah penelitian deskriptif survey. Populasi dalam penelitian ini adalah seluruh soal ujian semester ganjil mata pelajaran biologi. Sampel penelitian diambil secara stratified sampling yang berjumlah 25 soal pada setiap tingkatan kelasnya. Data dalam penelitian ini diperoleh dengan cara mengambil soal yang telah terdokumentasi. Data kemudian dianalisis sesuai dengan kata kerja operasional dimensi proses kognitif Taksonomi Anderson serta dikelompokkan sesuai dengan kompetensi dasar dan indikator pada silabus. Hasil penelitian menunjukkan bahwa: (1) Sebaran dimensi proses kognitif Taksonomi Anderson pada soal belum merata, soal didominasi oleh dimensi proses kognitif level mengingat (C1) dan m emahami (C2). (2) Rata-rata sebaran dimensi proses kognitif Taksonomi Anderson pada soal yaitu pada dimensi proses kognitif level C1 sebesar 41,3\%, C2 sebesar 37,3\%, C3 sebesar 13,3\%, C4 sebesar 5,3\%, C5 sebesar 2,7\% dan C6 sebesar 0\%. (3) Persebaran Kompetensi Dasar dan Indikator pada soal belum merata.
\end{abstract}

Keywords: Analisis Soal Ujian Akhir, Dimensi Proses Kognitif, Indikator, Kompetensi Dasar, Taksonomi Anderson

\begin{abstract}
This study aims to analyze the distribution of dimensions of the cognitive process of Anderson's Taxonomy and the distribution of basic competencies and indicators on final exams of first semester question. This research was conducted in SMA Negeri 1 Kisaran learning year 2017/2018. The type of research is descriptive survey. The population in this study is all the biology final exams of first semester questions in biology subjects. The research sample was taken stratified sampling with 25 questions at each grade level. The data in this study were obtained by taking the documented questions. Data were than analyzed according to the operational verb dimension of the cognitive process of Anderson's Taxonomy and grouped according to basic competencies and indicators in the syllabus. The results showed that: (1) The distribution dimensions of the cognitive process of Anderson's Taxonomy on questions is not evenly distributed, the question is dominated by the dimensions of the level process cognitive remembering (C1) and understanding (C2). (2) Average distribution of dimensions of the cognitive process of Anderson's Taxonomy on the question is the C1 level of cognitive processes in the amount of $41,3 \%, \mathrm{C} 2$ in the amount of 37,3\%, C3 in the amount of 13,3\%, C4 in the amount of 5,3\%, C5 in the amount of $2,7 \%$ and $\mathrm{C} 6$ in the amount of $0 \%$. (3) Distribution of basic competencies and indicators on the question is not evenly distributed.
\end{abstract}

Keywords: Analysis of Final Exams, Anderson's Taxonomy, Basic Competence,Cognitive Process Dimension, Indicator

\section{PENDAHULUAN}

Ujian akhir semester merupakan salah satu bentuk tes yang di terapkan sekolah. Soal ujian akhir semester (UAS) merupakan alat pada evaluasi sumatif yang digunakan guru untuk menilai keberhasilan siswa dalam penguasaan kompetensi pembelajaran di akhir pembelajaran atau pada akhir semester. Evaluasi sumatif merupakan evaluasi tahap akhir yang penting dilakukan untuk menetukan posisi siswa dalam suatu proses pembelajaran. Melalui evaluasi 
Halaman : 185- 192

sumatif guru dapat mengetahui keberhasilan setiap siswa dalam memahami materi yang diajarkan selama satu semester atau bahkan setelah selesai pembahasan suatu bidang studi. Dalam pembuatan soal diperlukan adanya tahapan penyusunan soal sehingga dapat ditarik kesimpulan seberapa besar penguasaan siswa terhadap indikator dan kompetensi dasar yang ingin dicapai. Namun kenyataan yang terjadi di sekolah, guru jarang menyusun tes dan biasanya menggunakan soal yang sudah ada kemudian disesuaikan dengan materi ajar (Osnal, dkk, 2016).

Selain itu, soal yang dijadikan bahan evaluasi pada ujian akhir semester sering kali tidak melalui tahapan analisis kualitas butir soal, sehingga belum diketahui kualitas soal yang telah disusun. Oleh karena itu, untuk mengetahui kualitas butir soal yang digunakan untuk tes perlu dilakukan analisis butir soal (Kurniawan, 2015).

Sebagai alat evaluasi, UAS memiliki manfaat diantaranya, usaha perbaikan melalui umpan balik, untuk menaksir apakah siswa benarbenar memahami pembelajaran seperti yang diharapkan, untuk memotivasi siswa, dan untuk membantu siswa dalam usaha atau karya bidang akademik. Nilai pada tes sumatif dijadikan sebagai catatan kemajuan belajar siswa dan penentu seorang siswa dapat atau tidaknya menerima program berikutnya.

SMA Negeri 1 Kisaran merupakan sekolah yang menerapkan kurikulum 2013 pada tingkatan siswa kelas X dan XI sementara untuk siswa kelas XII masih menggunakan kurikulum KTSP. Menurut Badan Akreditasi Nasional Sekolah/Madrasah (BANSM) (2015), SMA Negeri 1 Kisaran merupakan salah satu sekolah berakreditasi A di Kabupaten Asahan dengan perolehan nilai tertinggi yaitu sembilan puluh enam. Berdasarkan hasil observasi dan wawancara yang telah dilakukan dengan wakil kepala sekolah bidang kurikulum SMA Negeri 1 Kisaran, diketahui bahwa soal ujian akhir semester ganjil tahun pembelajaran 2017/2018 berupa 25 soal objektif berbentuk pilihan berganda yang disusun sendiri oleh guru pengampu bidang studi biologi di SMA Negeri 1 Kisaran disetiap tingkatan kelasnya. Soal (tes) pilihan berganda merupakan jenis tes objektif yang paling banyak digunakan oleh para guru. Hal ini dikarenakan item tes pilihan berganda efektif untuk mengukur tercapai tidaknya tujuan belajar mengajar, selain itu juga item tes pilihan berganda dapat mencakup seluruh bahan pembelajaran yang diberikan guru didalam kelas serta dapat mengukur kemampuan intelektual atau kognitif siswa (Sukardi, 2009).

Soal ujian yang sudah dibuat untuk ujian akhir semester telah dianalisis oleh guru yang bersangkutan. Namun dalam hal ini, belum pernah ada peneliti yang melakukan penelitian tentang menganalisis soal ujian akhir semester ganjil yang diujikan kepada siswa. Soal yang diujikan kepada siswa dirumuskan tanpa menyusun kisi-kisi soal terlebih dahulu, sehingga belum dapat dipastikan apakah soal-soal yang telah dibuat sudah sesuai dengan kompetensi dasar maupun indikator yang dimuat didalam silabus. Jika kualitas soal belum diketahui secara pasti, maka akan berpengaruh pada kecenderungan kesalahan penafsiran hasil tes.

Bloom (2015) mengemukakan bahwa dari bahan evaluasi hasil belajar yang disusun sekolah, persentase terbanyak butir soal yang diajukan hanya meminta siswa untuk mengutarakan hafalan mereka dan hafalan merupakan tingkatan terendah dalam kemampuan berpikir. Hal ini akan berdampak pada ketidakmampuan mengukur kemampuan berpikir tingkat tinggi siswa dan persentase persebaran butir soal tidak memenuhi proporsi yang seharusnya. Pada jenjang SMA level kognitif yang disajikan seharusnya sudah mencapai kemampuan menganalisis, mengevaluasi dan mencipta (soal HOT). Menurut Septiana (2016), proporsi soal untuk persebaran dimensi proses kognitif tingkat SMA/MA yang semestinya ialah $30 \%$ soal untuk C1 dan C2, $40 \%$ soal untuk C3 dan C4, dan $30 \%$ soal untuk C5 dan C6.

\section{METODE PENELITIAN}

Penelitian ini dilakukan di SMA Negeri 1 Kisaran yang berada di Jalan Madong Lubis No. 5, Kode Pos 21223, pada bulan Desember 2017 hingga Agustus 2018. Populasi dalam penelitian ini adalah seluruh soal ujian akhir semester ganjil 
Halaman : 185- 192

mata pelajaran biologi di SMA Negeri 1 Kisaran tahun pembelajaran 2017/2018. Sampel dalam penelitian ini diambil dengan menggunakan teknik stratified sampling. Penelitian ini menggunakan sampel total, yaitu seluruh butir soal ujian akhir semester ganjil biologi tahun pembelajaran 2017/2018 berbentuk pilihan berganda yang berjumlah 75 soal.

Penelitian yang dilakukan merupakan penelitian deskripstif survey. Penelitian ini dilakukan dengan cara menganalisis persebaran setiap level dimensi proses kognitif Taksonomi Anderson pada soal ujian akhir semester ganjil mata pelajaran biologi dengan cara mengelompokkan soal sesuai dengan kata kerja yang terdapat pada soal dan menganalisis persebaran kompetensi dasar dan indikator pada soal.

\section{HASIL PENELITIAN}

\section{Sebaran Dimensi Proses Kognitif Taksonomi Anderson}

Sebaran dimensi proses kognitif Taksonomi Anderson pada setiap levelnya terhadap soal ujian akhir semester ganjil mata pelajaran biologi SMA Negeri 1 Kisaran tahun pembelajaran 2017/2018 belum merata.

Tabel 1. Sebaran Dimensi Proses Kognitif Taksonomi Anderson pada Soal Ujian

\begin{tabular}{|c|c|c|c|c|c|c|c|c|}
\hline \multirow{2}{*}{ No } & \multirow{2}{*}{ Kelas } & \multicolumn{6}{|c|}{ Persentase Dimensi Proses Kognitif } & \multirow{2}{*}{$\Sigma$} \\
\hline & & $\mathrm{C} 1$ & $\mathrm{C} 2$ & $\mathrm{C} 3$ & $\mathrm{C} 4$ & $\mathrm{C} 5$ & C6 & \\
\hline 1 & $\mathrm{X}$ & 40 & 40 & 12 & 4 & 4 & 0 & 100 \\
\hline 2 & $X I$ & 76 & 24 & 0 & 0 & 0 & 0 & 100 \\
\hline 3 & XII & 8 & 48 & 28 & 12 & 4 & 0 & 100 \\
\hline \multicolumn{2}{|r|}{ Rata-Rata } & 41,3 & 37,3 & 13,3 & 5,3 & 2,7 & 0 & 100 \\
\hline \multicolumn{2}{|r|}{ Kategori } & & LOT & & & HOT & & \\
\hline
\end{tabular}

Berdasarkan Tabel 1, dimensi proses kognitif yang paling banyak digunakan pada soal ujian SMA Negeri 1 Kisaran yaitu pada level C1 dengan rata-rata sebesar $41,3 \%$ sedangkan level C6 tidak ditemukan terdapat pada soal. Pada kelas $X$ sebaran dimensi proses kognitif yang tertinggi terdapat pada level C1 dan C2 yaitu 40\%. Kelas XI sebaran dimensi proses kognitif yang tertinggi terdapat pada level C1 yaitu $76 \%$. Kelas XII sebaran dimensi proses kognitif yang tertinggi terdapat pada level C2 yaitu $48 \%$.

\section{Sebaran Kompetensi Dasar dan Indikator} Kelas X

Persebaran kompetensi dasar dan indikator kelas $\mathrm{X}$ pada soal dapat dikategorikan kurang baik, karena setelah dilakukan analisis dengan cara memilah soal kemudian menggolongkan soal sesuai dengan KD dan indikator yang tertera pada silabus, terdapat satu soal yang tidak sesuai dengan kompetensi dasar dan indikator.
Distribusi KD tertinggi terdapat pada KD 3.1, "Memahami tentang ruang lingkup biologi (permasalahan pada berbagai obyek biologi dan tingkat organisasi kehidupan), metode ilmiah dan prinsip keselamatan kerja berdasarkan pengamatan dalam kehidupan sehari-hari" dengan jumlah 6 soal (24\%) dan jumlah soal terendah terdapat pada KD 3.2, "Menganalisis data hasil obervasi tentang berbagai tingkat keanekaragaman hayati (gen, jenis dan ekosistem) di Indonesia, KD 3.5, “Menerapkan prinsip klasifikasi untuk menggolongkan protista berdasarkan cirri - cirri umum kelas dan perannya dalam kehidupan melalui pengamatan secara teliti dan sistematis serta KD 4.6 "Menyajikan data hasil pengamatan ciri-ciri dan peran jamur dalam kehidupan dan lingkungan dalam bentuk laporan tertulis" sebanyak 1 soal (4\%). Indikator yang paling banyak digunakan yaitu indikator 3.4.1 "Menjelskan ciri-ciri archebacteria dan eubacteria" sebanyak 4 soal (12\%). 
Halaman : 185- 192

Tabel 2. Persentase Sebaran Kompetensi Dasar dan Indikator pada Soal Kelas X

\begin{tabular}{|c|c|c|c|c|c|c|}
\hline No & $\begin{array}{c}\text { Kompetensi Dasar } \\
\text { (KD) }\end{array}$ & $\begin{array}{c}\text { Jumlah } \\
\text { Soal }\end{array}$ & $\begin{array}{c}\text { Persentase } \\
(\%)\end{array}$ & Indikator & $\begin{array}{c}\text { Jumlah } \\
\text { Soal }\end{array}$ & $\begin{array}{c}\text { Persentase } \\
(\%)\end{array}$ \\
\hline \multirow[t]{4}{*}{1} & 3.1 & 6 & 24,0 & 3.1 .1 & 1 & 4,0 \\
\hline & & & & 3.1 .3 & 2 & 8,0 \\
\hline & & & & 3.1 .9 & 1 & 4,0 \\
\hline & & & & 3.1 .10 & 2 & 8,0 \\
\hline 2 & 3.2 & 1 & 4,0 & 3.2 .1 & 1 & 4,0 \\
\hline \multirow[t]{5}{*}{3} & 3.3 & 5 & 20,0 & 3.3 .1 & 1 & 4,0 \\
\hline & & & & 3.3 .3 & 1 & 4,0 \\
\hline & & & & 3.3 .4 & 1 & 4,0 \\
\hline & & & & 3.3 .5 & 1 & 4,0 \\
\hline & & & & 3.3.13 & 1 & 4,0 \\
\hline \multirow[t]{2}{*}{4} & 3.4 & 5 & 20,0 & 3.4 .1 & 4 & 16,0 \\
\hline & & & & 3.4 .4 & 1 & 4,0 \\
\hline 5 & 3.5 & 1 & 4,0 & 3.5 .2 & 1 & 4,0 \\
\hline 6 & 4.5 & 2 & 8,0 & 4.5 .2 & 2 & 8,0 \\
\hline \multirow[t]{3}{*}{7} & 3.6 & 3 & 12,0 & 3.6 .1 & 1 & 4,0 \\
\hline & & & & 3.6 .3 & 1 & 4,0 \\
\hline & & & & 3.6 .5 & 1 & 4,0 \\
\hline 8 & 4.6 & 1 & 4,0 & 4.6 .3 & 1 & 4,0 \\
\hline 9 & - & 1 & 4,0 & - & 1 & 4,0 \\
\hline$\Sigma$ & 7 & 25 & 100 & 18 & 25 & 100 \\
\hline
\end{tabular}

Kelas XI

Persebaran kompetensi dasar dan indikator kelas $\mathrm{X}$ pada soal dapat dikategorikan kurang baik, karena setelah dilakukan analisis dengan cara memilah soal kemudian menggolongkan soal sesuai dengan KD dan indikator yang tertera pada silabus, terdapat satu soal yang tidak sesuai dengan kompetensi dasar dan dua soal yang tidak sesuai dengan indikator.

Tabel 3. Persentase Sebaran Kompetensi Dasar dan Indikator pada Soal Kelas XI

\begin{tabular}{|c|c|c|c|c|c|c|}
\hline No & $\begin{array}{c}\text { Kompetensi Dasar } \\
\text { (KD) }\end{array}$ & $\begin{array}{c}\text { Jumlah } \\
\text { Soal }\end{array}$ & $\begin{array}{c}\text { Persentase } \\
(\%)\end{array}$ & Indikator & $\begin{array}{c}\text { Jumlah } \\
\text { Soal }\end{array}$ & $\begin{array}{c}\text { Persentase } \\
(\%)\end{array}$ \\
\hline \multirow[t]{3}{*}{1} & 3.1 & 7 & 28,0 & 3.1 .4 & 2 & 8,0 \\
\hline & & & & 3.1 .5 & 4 & 16,0 \\
\hline & & & & - & 1 & 4,0 \\
\hline 2 & 3.3 & 1 & 4,0 & 3.3 .4 & 1 & 4,0 \\
\hline \multirow[t]{2}{*}{3} & 3.4 & 3 & 12,0 & 3.4 .1 & 2 & 8,0 \\
\hline & & & & 3.4 .2 & 1 & 4,0 \\
\hline \multirow[t]{3}{*}{4} & 3.5 & 9 & 36,0 & 3.5 .2 & 3 & 12,0 \\
\hline & & & & 3.5 .4 & 2 & 8,0 \\
\hline & & & & 3.5 .5 & 4 & 16,0 \\
\hline \multirow[t]{2}{*}{5} & 3.6 & 2 & 8,0 & 3.6 .2 & 1 & 4,0 \\
\hline & & & & 3.6 .5 & 1 & 4,0 \\
\hline 6 & 3.10 & 2 & 8,0 & 3.10 .2 & 2 & 8,0 \\
\hline 7 & - & 1 & 4,0 & - & 1 & 4,0 \\
\hline$\Sigma$ & 6 & 25 & 100 & 11 & 25 & 100 \\
\hline
\end{tabular}

Distribusi KD tertinggi terdapat pada KD 3.5, "Menganalisis hubungan antara struktur jaringan penyusun organ pada sistem gerak dan mengaitkan dengan bioprosesnya sehingga dapat menjelaskan mekanisme gerak serta gangguan fungsi yang mungkin terjadi pada sistem gerak 
Halaman : 185- 192

manusia melalui studi literatur, pengamatan, percobaan, dan simulasi" dengan jumlah 9 soal (36\%) dan distribusi KD terendah terdapat pada KD 3.3, "Menerapkan konsep tentang keterkaitan hubungan antara struktur sel pada jaringan tumbuhan dengan fungsi organ pada tumbuhan berdasarkan hasil pengamatan" sebanyak 1 soal (4\%). Indikator yang paling banyak digunakan yaitu indikator 3.1.5, “Menjelaskan fungsi masingmasing organel yang dimiliki sel hewan dan sel tumbuhan" dan indikator 3.5.5, "Menganalisis jenis gerakan dan organ gerak yang berfungsi dalam berbagai kegiatan gerak yang dilakukan/diperagakan dan mengaitkan prosesproses gerak yang dilakukan dengan kelainan yang mungkin terjadi", sebanyak 4 soal (16\%)

\section{Kelas XII}

Persebaran kompetensi dasar dan indikator kelas $\mathrm{X}$ pada soal dapat dikategorikan kurang baik, karena setelah dilakukan analisis dengan cara memilah soal kemudian menggolongkan soal sesuai dengan KD dan indikator yang tertera pada silabus, terdapat dua soal yang tidak sesuai dengan kompetensi dasar dan indikator.

Tabel 4. Persentase Sebaran Kompetensi Dasar dan Indikator pada Soal Kelas XII

\begin{tabular}{|c|c|c|c|c|c|c|}
\hline No & $\begin{array}{l}\text { Kompetensi Dasar } \\
\text { (KD) }\end{array}$ & $\begin{array}{c}\text { Jumlah } \\
\text { Soal }\end{array}$ & $\begin{array}{c}\text { Persentase } \\
(\%)\end{array}$ & Indikator & $\begin{array}{c}\text { Jumlah } \\
\text { Soal }\end{array}$ & $\begin{array}{c}\text { Persentase } \\
(\%)\end{array}$ \\
\hline 1 & 1.1 & 2 & 8,0 & 1.1 .1 & 2 & 8,0 \\
\hline 2 & 1.2 & 1 & 4,0 & 1.2 .4 & 1 & 4,0 \\
\hline \multirow[t]{2}{*}{3} & 2.1 & 2 & 8,0 & 2.1 .1 & 1 & 4,0 \\
\hline & & & & 2.1 .3 & 1 & 4,0 \\
\hline \multirow[t]{2}{*}{4} & 2.2 & 3 & 12,0 & 2.2 .2 & 2 & 8,0 \\
\hline & & & & 2.2 .3 & 1 & 4,0 \\
\hline \multirow[t]{2}{*}{5} & 3.1 & 5 & 20,0 & 3.1 .1 & 2 & 8,0 \\
\hline & & & & 3.1 .3 & 3 & 12,0 \\
\hline 6 & 3.2 & 1 & 4,0 & 3.2 .2 & 1 & 4,0 \\
\hline 7 & 3.3 & 4 & 16,0 & 3.3.3 & 4 & 16,0 \\
\hline \multirow[t]{2}{*}{8} & 3.4 & 5 & 20,0 & 3.4 .1 & 3 & 12,0 \\
\hline & & & & 3.4 .2 & 2 & 8,0 \\
\hline 9 & - & 2 & 8,0 & - & 2 & 8,0 \\
\hline$\Sigma$ & 8 & 25 & 100 & 12 & 25 & 100 \\
\hline
\end{tabular}

Distribusi KD tertinggi terdapat pada KD 3.1, "Menjelaskan konsep gen, DNA, dan kromosom" dan KD 3.4, "Menerapkan prinsip hereditas dalam mekanisme pewarisan sifat" sebanyak 5 soal (20\%) dan distribusi KD terendah terdapat pada KD 1.2, "Melaksanakan percobaan pengaruh faktor luar terhadap pertumbuhan tumbuhan" dan KD 3.2, "Menjelaskan hubungan gen (DNA)-RNApolipeptida dan proses sintesis protein" sebanyak 1 soal (4\%). Indikator yang paling banyak digunakan yaitu indikator 3.3.3 "Mendeskripsikan fase-fase pembelahan dan tempat terjadinya mitosis dan meiosis" sebanyak 4 soal (16\%).

\section{PEMBAHASAN}

Dari hasil penelitian, berdasarkan sebaran dimensi proses kognitif Taksonomi Anderson soal didominasi pada level mengingat (C1) dan level memahami (C2) yang berarti soal banyak terfokus pada topik/materi yang sifatnya hafalan. Pada kelas X, soal didominasi oleh soal LOT (Lower Order Thinking) sebesar 92\%. Pada level mengingat (C1) dan memahami (C2) terdiri dari 10 soal (40\%), level menerapkan (C3) terdiri dari 3 soal (12\%), level menganalisis (C4) dan mengevaluasi (C5) terdiri dari 1 soal (4\%). Sementara pada level mencipta (C6), tidak tersentuh sama sekali. Soal ujian akhir semester ganjil biologi kelas $\mathrm{X}$ memperoleh perbandingan 
Halaman : 185- 192

$80 \%$ soal mudah: $16 \%$ soal sedang: $4 \%$ soal sukar. Marsiyah (2016) dalam penelitiannya mengenai analisis soal buatan guru biologi kelas X SMA Muhammadiyah 1 Surakarta juga mendapati hasil yang serupa yaitu soal didominasi oleh soal mudah dengan perbandingan dimensi proses kognitif sebesar $56 \%$ soal mudah: $24 \%$ soal sedang: $20 \%$ soal sukar. Soal tes dikatakan baik jika soal tersebut tidak terlalu mudah atau terlalu sukar (Friatma, dkk, 2017). Hasil yang diperoleh pada penelitian dikategorikan kurang baik, karena perbandingan soal yang baik yaitu $30 \%$ soal mudah: $40 \%$ soal sedang: $30 \%$ soal sukar (Septiana, 2016).

Sementara itu pada soal ujian akhir semester ganjil dikelas $\mathrm{XI}$, dimensi proses kognitif Taksonomi Anderson yang digunakan pada soal hanya pada level mengingat (C1) sebanyak 19 soal (76\%) dan level memahami (C2) sebanyak 6 soal (24\%). Tidak terdapat level mengaplikasikan (C3), menganalisis (C4), mengevaluasi (C5) serta mencipta (C6) pada soal. Seluruh soal ujian akhir semester ganjil kelas XI merupakan soal LOT (Lower Order Thinking). Soal pada level mengingat (C1) merupakan soal yang mudah di kerjakan oleh siswa namun hal ini akan menyebabkan kecenderung siswa menghafal materi untuk mendapatkan nilai yang baik (Arti dan Hariyatmi, 2015). Menurut Oktavianti (2017), apabila siswa terus dibiasakan dengan soal-soal yang tergolong mudah, hal ini tidak akan berdampak baik kedepannya karena siswa akan terbiasa untuk mengingat dan sekedar memahami saja, selain itu hal ini juga akan berdampak pada berkurangnya rasa ingin tau siswa yang kemudian menyebabkan rendahnya kemampuan siswa untuk menciptakan hal baru.

Berbeda dengan kelas $\mathrm{X}$ dan $\mathrm{XI}$, pada soal ujian akhir semester ganjil kelas XII, soal didominasi oleh level memahami (C2) yang terdiri dari 12 soal (48\%), sedangkan pada level mengingat (C1) terdiri dari 2 soal (8\%), level mengaplikasikan (C3) terdiri dari 7 soal (28\%), level menganalisis (C4) terdiri dari 3 soal (12\%), level mengevaluasi terdiri dari 1 soal (4\%). Adapun proporsi dimensi proses kognitif Taksonomi
Anderson pada soal kelas XII sebesar $56 \%$ soal mudah: $40 \%$ soal sedang: $4 \%$ soal sukar. Proporsi soal sedang sudah sesuai dengan proporsi yang semestinya, namun proporsi soal mudah dan soal sukar masih jauh dari proporsi dimensi proses kognitif Taksonomi Anderson. Hasil analisis disetiap tingkatan kelas menunjukkan ketidaksesuaian antara proporsi soal ditinjau dari Taksonomi Anderson dengan proporsi yang semestinya di tingkat SMA/MA. Soal didominasi pada kategori soal LOT (Lower Order Thinking). Rata-rata sebaran soal yang diperoleh, baik dari level mengingat hingga mencipta dapat dikatakan masih jauh dari proporsi yang seharusnya. Hal ini disebabkan oleh terabaikannya Taksonomi Anderson karena soal yang digunakan pada saat ujian akhir semester ganjil diambil secara acak dari buku cetak serta LKS yang digunakan pada proses pembelajaran.

Persebaran Kompetensi Dasar pada soal ujian akhir semester ganjil biologi juga tidak merata. Pada kelas $X$ jumlah KD yang digunakan sebanyak 7. Dari hasil analisis diketahui bahwa KD tertinggi terdapat pada KD 3.1 (24\%) sedangkan KD terendah terdapat pada KD 3.2, KD 3.5 dan KD 4.6 (4\%) serta terdapat satu soal yang tidak memuat KD yang tertera pada silabus. Pada Kelas XI jumlah KD yang digunakan sebanyak 6 . Dari hasil analisis diketahui bahwa KD tertinggi terdapat pada KD 3.5 (36\%) sedangkan KD terendah terdapat pada KD 3.3 (4\%). Sama hal nya dengan kelas $X$, pada kelas $\mathrm{XI}$ juga ditemukan 1 soal yang tidak memuat KD yang tertera pada silabus. Pada kelas XII jumlah KD yang digunakan sebanyak 8. Berdasarkan hasil analisis KD tertinggi terdapat pada KD 3.1 dan KD 3.4 (20\%) sedangkan KD terendah pada KD 1.2 dan KD 3.2 (4\%) serta terdapat 2 soal yang tidak memuat $K D$ yang tertera pada silabus.

Jumlah KD dalam satu semester untuk kelas $\mathrm{X}$ berjumlah 10, kelas XI berjumlah 14 dan kelas XII berjumlah 11. Hasil analisis menunjukkan persentase persebaran KD tidak merata baik dari kelas $\mathrm{X}$ hingga kelas XII, hanya terdapat satu atau dua KD yang mendominasi pada soal. Ujian akhir semester semestinya mencakup semua KD pada semester tersebut. Agar terwakilkan, sebaiknya 
Halaman : 185- 192

jumlah soal per KD untuk kelas $X$ antara 2 hingga 3 soal, kelas XI antara 1 hingga 2 soal, dan XII antara 2 hingga 3 soal.

Ditinjau dari sebaran indikator pada alat evaluasi berupa soal ujian akhir semester ganjil, di kelas $\mathrm{X}$ menggunakan 18 indikator, dengan indikator tertinggi terdapat pada 3.4 .1 (12\%). Dari hasil analisis terdapat 1 soal yang tidak mengacu pada indikator.Pada kelas XI digunakan 11 indikator dengan indikator tertinggi terdapat pada 3.1.5 dan indikator 3.5.5 (20\%). Sama halnya dengan soal ujian kelas $\mathrm{X}$, pada kelas $\mathrm{XI}$ juga ditemukan 1 soal yang tidak mengacu pada indikator. Kelas XII jumlah indikator yang digunakan yaitu 12 indikator dengan indikator tertinggi pada 3.3.3 (16\%). Pada soal ujian kelas XII terdapat 2 soal yang tidak mengacu pada indikator. Jumlah indikator dalam satu semester untuk kelas $\mathrm{X}$ berjumlah 84 , kelas XI berjumlah 77 dan kelas XII berjumlah 37 . Ujian akhir semester ganjil merupakan suatu kegiatan yang dilakukan oleh pendidik untuk mengukur pencapaian kompetensi peserta didik di akhir semester ganjil. Cakupan soal yang diujikan meliputi seluruh indikator yang mempresentasikan semua kompetensi dasar. Jika soal yang diujikan dalam penyusunannya masih ada yang tidak sesuai dengan indikator maka perlu dilakukan evaluasi kembali. Karena indikator merupakan acuan dalam pembuatan soal, di dalam indikator tergambar level kognitif yang harus dicapai dalam KD, memuat ciri-ciri KD yang akan diukur, mengandung kata kerja operasional yang dapat diukur, serta berkaitan dengan materi yang dipilih dan sebagainya (Kemdikbud, 2017).

Hasil analisis menunjukkan, baik pada persebaran dimensi proses kognitif Taksonomi Anderson maupun KD dan Indikator terjadi ketidak sesuaian dengan yang semestinya. Hal ini dapat terjadi karena pada saat penyusunan soal ujian tidak melalui prosedur penyusunan soal. Jika soal ujian akhir semester ganjil disusun sesuai dengan prosedur yang semestinya, maka soal yang digunakan akan mewakili isi kurikulum secara tepat. Selain itu proporsi dimensi proses kognitif di setiap levelnya juga akan merata, karena soal merupakan jabaran atau wujud dari indikator yang mengandung kata kerja operasional sehingga dalam penyusunan soal dapat disesuaikan jumlah soal sesuai proporsi di setiap level dimensi proses kognitif Taksonomi Anderson. Suatu tes dapat dikatakan sahih/benar jika telah memenuhi kriteria validitas kurikuler, yaitu apabila aspek-aspek yang dipersoalkan dalam tes sesuai dengan KD dan indikator (Purwanto, 2014). Jika instrumen evaluasi kurang baik, maka dapat berakibat hasil evaluasi menjadi kurang baik pula. Namun, jika instrumen evaluasi yang digunakan sudah disusun sesuai dengan yang semestinya, hal ini dapat berdampak baik, diantaranya dapat memberikan informasi sejauh mana suatu program berhasil diterapkan, mengetahui kelemahan siswa serta sebab kelemahan tersebut dan cara mengatasinya, mendeteksi siswa yang telah dan belum menguasai tujuan pembelajaran dan sebagainya (Mahirah, 2017).

\section{KESIMPULAN}

Sebaran dimensi proses kognitif Taksonomi Anderson pada soal ujian akhir semester ganjil mata pelajaran biologi di kelas $X$, XI, XII SMA Negeri 1 Kisaran tahun pembelajaran 2017/2018 belum merata. Soal lebih dominan mengunakan dimensi proses kognitif level mengingat (C1) dan memahami (C2). Persebaran kompetensi dasar dan indikator pada soal belum merata. Terdapat kompetensi dasar dan indikator yang tidak dimuat dalam soal.

\section{DAFTAR PUSTAKA}

Bloom, (2015), Analisis Hasil Belajar Matematika Siswa pada Pokok Bahasan Himpunan Berdasarkan Ranah Kognitif Taksonomi Bloom Kelas VII-A di SMPN 14 Jember, Jurnal Edukasi UNEJ, 2(1): 2.

Badan Akreditasi Nasional Sekolah/Madrasah, (2015), Akreditasi Sekolah Menengah Atas Negeri Asahan, https://bansm.kemdikbud.go.id, Diakses pada 4 Januari 2018.

Mahirah, B., (2017), Evaluasi Belajar Peserta Didik (Siswa), Jurnal Idaarah, 1(2): 266. 
Halaman : 185- 192

Friatma, A., Syamsurizal, dan Helendra, (2017), Analisis Kualitas Soal Ujian Akhir Semester Genap Mata Pelajaran Biologi Kelas XI IPA SMA Negeri Wilayah Selatan Kabupaten Solok Tahun Pelajaran 2015/2016, Bioeducation Journal, 1(2): 52.

Kemdikbud, (2017), Panduan Penulisan Soal SMA/MA-SMK, Pusat Penilaian Pendidikan Badan Penelitian dan Pengembangan Kementerian Pendidikan dan Kebudayaan, Jakarta.

Kurniawan, T., (2015), Analisis Butir Soal Ulangan Akhir Semester Gasal Mata Pelajaran IPS Sekolah Dasar, Journal of Elementary Education, 4(1): 2.

Marsiyah, F., (2016), Analisis Soal Ulangan Harian Buatan Guru Biologi SMA Muhammadiyah 1 Surakarta Tahun Ajaran 2015/2016 Ditinjau dari Tingkat Taksonomi Bloom, Publikasi Ilmiah.

Osnal, Suhartoni, dan Imam, W., (2016), Meningkatkan Kemampuan Guru Dalam Menyusun Tes Hasil Belajar Akhir Semester Melalui Workshop di KKG Gugus 02 Kecamatan Sumbermalang Tahun 2014/2015, Pancaran, 5(1): 68.

Purwanto, E., (2014), Evaluasi Proses dan Hasil dalam Pembelajaran, Penerbit Ombak, Yogyakarta.

Septiana, N., (2016), Analisis Butir Soal Ulangan Akhir Semester (UAS) Biologi Tahun Pelajaran 2015/2016 Kelas X dan XI pada MAN Sampit, Jurnal EduSains, 4(2): 118.

Sukardi, H. M., (2009), Evaluasi Pendidikan Prinsip dan Operasionalnya, Bumi Aksara, Jakarta. 